\title{
Research on the Influencing Factors of C2C WeChat Business Credit
}

\author{
Gao Wei ${ }^{1, a^{*}}$, Chen Hongquan ${ }^{1}$, Yan Ruzhen ${ }^{2}$ \\ ${ }^{1}$ Business School, Sichuan Agricultural University, Chengdu, China \\ ${ }^{2}$ Business School, Chendu University of Technology, Chengdu, China \\ a E-mail: gaow956@163.com
}

Key words: WeChat business; credit problem; influencing factors

Abstract. Micro-business has developed rapidly in recent years. The WeChat business credit problem is becoming more and more important. In this paper, we study on the WeChat business credit problem, analyze the influence of factors in the WeChat business credit. Relevant results provide a basis for the establishment of WeChat business's credibility evaluation system, and develop the suggestion to solve WeChat business credit problem and promote WeChat business development.

\section{Introduction}

$\mathrm{C} 2 \mathrm{C}$ WeChat business is a new business form. In this form, the merchants releases information on WeChat circle of friends, sales goods to friends who like commodities. In the process, social platforms serve as informational platforms. With the lack of a WeChat business trading regulatory platform, the trading model is almost "no threshold, no regulation". Obviously, the reason that the whole trading can be executed is the mutual credit. Therefore, the credit is particularly important for the the WeChat business.

Currently, the biggest problem with WeChat business is still credit problem. On the one hand, the trading system and payment system of WeChat business are imperfect. The distrust problem prevails in WeChat business[1-3]. On the other hand, with the development of WeChat business, the deceptive software makes consumers distrust WeChat business, such as WeChat dialogue generator, Alipay transfer truncation device. Therefore, the problem of credit crisis is the most urgent problem for the whole WeChat industry.

Qian et al.(2016) studies the problem of "Problems in the development of WeChat business"[4]. Yin et al.(2015) suggests that WeChat businessman should establish the credit relationship with consumer in three aspects, such as improving customer satisfaction, increasing brand popularity and building a perfect after-sales service system[5]. Zuo(2016) presents that the method to solve the credit problem is to promote the standardized development of WeChat business[6]. In this paper, we establish a WeChat business credit evaluation system, and analyze the weight of the influence factors. This work provides the basis for the establishment of WeChat business credit evaluation system.

\section{The trading mode construction and analysis}

In this paper, we study the intrinsic influence of WeChat business, and develop theory the influencing factors model of WeChat business credit problem. Now we make the following assumptions: 


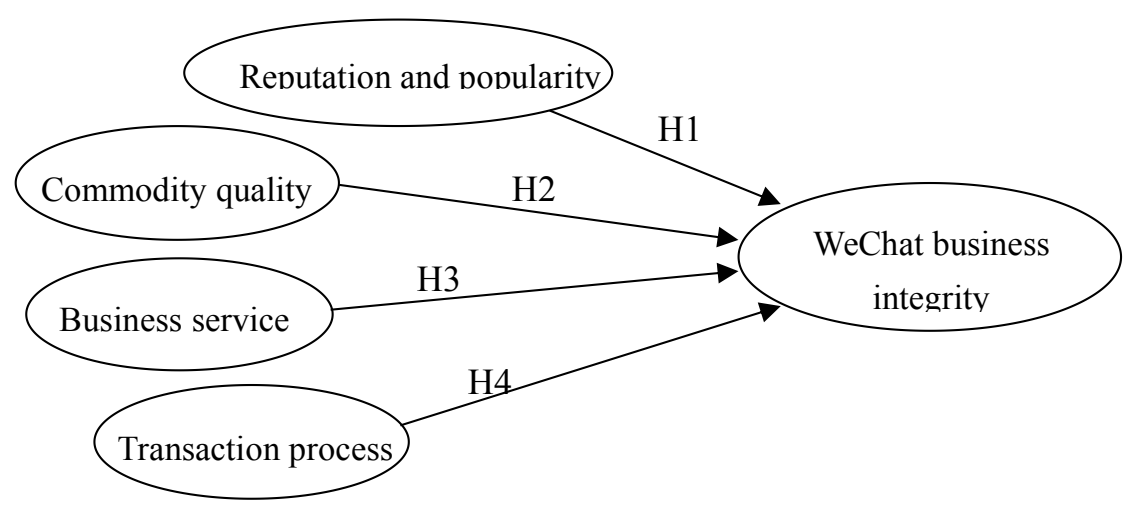

Fig1 The trading model

H1: Reputation and popularity has an impact on WeChat business credit

$\mathrm{H} 2$ : Commodity quality has an impact on WeChat business credit

H3: Business Service has an impact on WeChat business credit

H4: Transaction process has an impact WeChat business credit

In this paper, we develop the questionnaire by the Likert five-level scale. In order to reflect the respondents attitude, we develop 13 indicators (Table 1).

Table1 Variable measurement

\begin{tabular}{|l|l|}
\hline Variable & Variable measurement \\
\hline peputation and & A1: I will consider buying something in a friend's recommended micro-business. \\
& A2: I will consider buying something in the more popular micro-business.
\end{tabular}

Using the method of random sampling, we distributed 200 questionnaires and collected them all. Excluding questionnaires with incorrect or missing information, there are 189 valid questionnaires. Cronbach's $\alpha$ is the most commonly used confidence level factor. The value of $\alpha$ is generally greater than 0.8 . The results show in Table 2 .The alpha values are above 0.8 for the four potential variables. From Table 2 , there is a good internal consistency.

Table 2 The value of $\alpha$ and AVE

\begin{tabular}{|c|c|c|c|}
\hline Potential variable & Cronbach's alpha & Number of items & AVE \\
\hline Reputation and popularity & 0.848 & 2 & 0.619 \\
\hline Business service & 0.825 & 3 & 0.728 \\
\hline Commodity quality & 0.885 & 4 & 0.653 \\
\hline Transaction process & 0.872 & 4 & 0.713 \\
\hline
\end{tabular}


Factor analysis method is used to analyze the structural validity, according to the KMO test to determine whether factor analysis method is used. In this paper, we use SPSS 19.0 to analyze the scale. The results show in the Table 3. KMO value is 0.873 . The Bartlett's of sphericity test approximates chi square is 937.755 . The results indicate that the scale has a good structural validity.

Table $3 \mathrm{KMO}$ and Bartlett inspection

\begin{tabular}{|l|c|c|}
\hline \multicolumn{2}{|c|}{ Kaiser-Meyer-Olkin metrics for sampling sufficiency } & .873 \\
\hline \multirow{3}{*}{ Sphericity test of Bartlett } & Approximate chi square & 937.755 \\
\cline { 2 - 3 } & $\mathrm{df}$ & 136 \\
\cline { 2 - 3 } & Sig. & .000 \\
\hline
\end{tabular}

The number of males is 64 , accounting for $33.9 \%$, the number of women is 125 , accounting for $66.1 \%$, mostly students aged $18-35$ years old. In the data, we can see that the female is the majority in the WeChat business. The results met our expectations and current situation. In order to further analyze this problem, this paper will analyze by the four point graph model. The four point graph model is also called the important factor into the model. In this paper, the vertical axis of our point graph is "the importance", the abscissa is "the actual credibility". The results shown in Fig.2.

In Fig.2, the WeChat business sellers should focus on the reputation and popularity, quality goods and after-sale service. In order to provide the high quality products to customers, the services and credit of the WeChat business sellers should pay more attention.

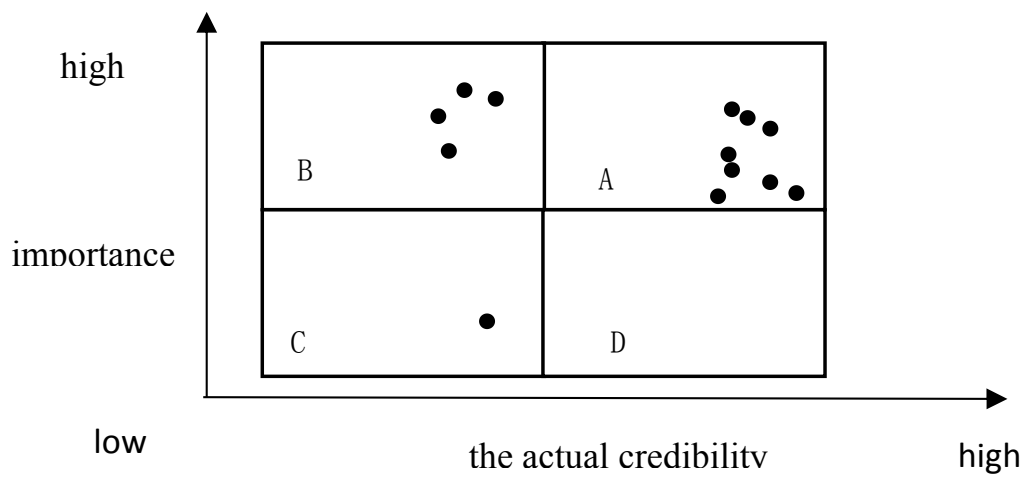

Fig.2 The four point graph model

In order to further analyze the relationship between independent variables and dependent variables, multivariate regression analysis was adopted to analyze the regression coefficients by the statistical software SPSS19.0. The results are shown in Table 4.

Table 4 Micro-business regression analysis coefficient table

\begin{tabular}{|c|c|c|c|c|c|}
\hline \multirow[b]{2}{*}{ Model } & \multicolumn{2}{|c|}{ non- normalized coefficient } & \multirow{2}{*}{$\frac{\text { standard coefficient }}{\text { Trial }}$} & \multirow[b]{2}{*}{$\mathrm{t}$} & \multirow[b]{2}{*}{ Sig. } \\
\hline & B & $\begin{array}{l}\text { Standard } \\
\text { Error }\end{array}$ & & & \\
\hline (Constant) & -0.252 & 0.039 & & 0.000 & 1.000 \\
\hline $\begin{array}{c}\text { Reputation and } \\
\text { popularity }\end{array}$ & 0.336 & 0.039 & 0.336 & 10.333 & 0.000 \\
\hline $\begin{array}{l}\text { Business } \\
\text { Services }\end{array}$ & 0.160 & 0.039 & 0.160 & 13.520 & 0.000 \\
\hline $\begin{array}{l}\text { Commodity } \\
\text { quality }\end{array}$ & 0.347 & 0.039 & 0.347 & 10.150 & 0.000 \\
\hline $\begin{array}{l}\text { Transaction } \\
\text { process }\end{array}$ & 0.249 & 0.039 & 0.249 & 11.266 & 0.000 \\
\hline
\end{tabular}




\section{Assumed test results}

The results show that six hypotheses are significantly supported, and the results are summarized as shown in Table5. We can see that the commodity quality has greater impact on WeChat business credit. The business services has the least influence on WeChat business credit.

Table 5 Assumed test results

\begin{tabular}{|c|c|c|}
\hline Assumption & the regression & coefficient conclusion \\
\hline $\begin{array}{l}\text { H1: reputation and popularity have a significant impact on } \\
\text { microbusiness credit }\end{array}$ & 0.336 & support \\
\hline $\begin{array}{l}\text { H2: business services have a significant impact on } \\
\text { microbusiness credit }\end{array}$ & 0.160 & support \\
\hline $\begin{array}{c}\text { H3: commodity quality has a significant impact on } \\
\text { microbusiness credit }\end{array}$ & 0.347 & support \\
\hline $\begin{array}{l}\text { H4: transaction process has a significant impact on } \\
\text { microbusiness credit }\end{array}$ & 0.249 & support \\
\hline
\end{tabular}

\section{Conclusions}

In this paper, we analyze the influence factors of WeChat business credit. The results show that the commodity quality has greater impact on WeChat business credit. The business services has the least influence on WeChat business credit. The results of this research can improve WeChat business credit, and promote the healthy and sustainable development of WeChat business.

\section{Acknowledgements}

This paper is supported by the Program of Undergraduate Thesis Foster of Sichuan Agriculture University (34009114), the National Natural Science Foundation of China (71501018), and Sichuan Province Soft Science Foundation (2017ZR0204).

\section{References}

[1] Z. Guo, Y. Zhang. Wechat business hall provide help for radio and tv industry development, Radio \& Television Information, 4(2016), 12-14.

[2] S. Yang, S. Chen, B. Li. The role of business and friendships on wechat business: an emerging business model in China, Journal of Global Marketing, 29(2016), 1-14.

[3] J. Zhu, S. O. La. Identification and regulation of reticent defraud of business operators under C2C Wechat business, Journal of Nantong University, 3(2015), 21-24.

[4] F. Y. Qian, J. Li, X. Liu. On the construction of trust mechanism of micro business modern business, Modern business, 9(2016), 50-51.

[5] Y. Y. Yin, W. H. Miao, S. N. Zhang. Micro-blogging trust mechanism research, Modern business, 12(2015), 27-28.

[6] L. M. Zuo. According to the law to strengthen the behavior of micro-traders trading countermeasures to micro-business situation as the perspective, Journal of North University (Social Science Edition), 1(2016), 27-29. 